\title{
Housing Policy in the Wake of the Crash
}

\section{Citation}

Glaeser, Edward L. "Housing Policy in the Wake of the Crash." Daedalus 139.4 (Fall 2010): 95-106.

\section{Published Version}

http://dx.doi.org/10.1162/DAED_a_00046

\section{Permanent link}

http://nrs.harvard.edu/urn-3:HUL.InstRepos:10611669

\section{Terms of Use}

This article was downloaded from Harvard University's DASH repository, and is made available under the terms and conditions applicable to Other Posted Material, as set forth at http:// nrs.harvard.edu/urn-3:HUL.InstRepos:dash.current.terms-of-use\#LAA

\section{Share Your Story}

The Harvard community has made this article openly available.

Please share how this access benefits you. Submit a story.

Accessibility 


\section{Edward L. Glaeser}

\section{Housing policy in the wake of the crash}

$\mathrm{B}$ ing market experienced a convulsion more extreme than in any previous recorded cycle. From May 2001 to May 2006, the Case/Shiller Standard \& Poor's twenty-city housing price index, which controls for changes in housing quality by comparing prices from repeat sales of the same homes, rose 54 percent more than consumer prices rose. In the three years that followed, housing prices, measured by the same index and corrected for inflation, fell more than one-third. Across metropolitan areas, the correlation between boom and bust was almost perfect. For every 10 percent that an area's prices increased between 2001 and 2006, that area's prices fell by 7.6 percent between 2006 and 2009. As prices plummeted, financial institutions that had exposed themselves to sizable housing-market risk became insolvent. The entire U.S. banking system seemed at risk.

The extreme housing-price swings were mirrored by equally oversized fluctuations in the construction industry. America typically produces about 1.5 million housing units annually, which is about 200,000 more than the rate of

(C) 2010 by the American Academy of Arts \& Sciences household formation. In both 2005 and 2006, builders completed more than 1.9 million new units, at least 580,000 more than the rate of household formation in each year. By a conservative estimate, America erected at least 2 million extra units, relative to historic standards, during the boom. By 2009, there were upwards of 5 million more vacant homes in the United States than there were in 2000. That glut, in turn, explains the decline in new construction and jobs: fewer than 800,000 units were built in 2009 ; the unemployment rate in the construction sector exceeded 20 percent in early 2010.

While the extremity of the cycle is clear, the causes of the great housing convulsion are more mysterious. Some economists have emphasized the role of easy credit and low interest rates. Certainly, as real and nominal rates fell, buyers benefited from cheaper mortgages, and credit-constrained purchasers were able to cover the costs of more expensive houses. But there is little evidence to support the view that changes in interest rates were large enough to explain the housing market's recent crash. On average, as interest rates decline by one percentage point, housing prices increase by roughly 6.8 percent. Even at very low interest rate levels in markets 
Edward L. Glaeser on the financial crisis \& economic policy where housing supply is limited, a onehundred-basis-point decrease in real rates does not push prices up more than 8 percent. Between 2000 and 2006, real interest rates fell by 1.3 percent, which suggests that falling rates can explain, at most, a 10.4 percent housing price rise.

Another view implicates aggressive mortgage approval or low loan-to-value ratios. Similarly, compelling evidence to support this explanation is hard to find. My work with economist Joshua Gottlieb and finance expert Joseph Gyourko ${ }^{1}$ has estimated that changes in approval rates explain about one-fifth to onethird of the price boom. Loan-to-value levels appear to have an even smaller impact, but the difficulty of controlling for changes in the pool of mortgage applications limits the value of this finding. Moreover, the results of our research are not meant to clear the Federal Reserve System, or anyone else, of error, but rather to emphasize that we cannot identify with any certainty what caused the boom or why it ended.

We do know, however, that individual buyers had wildly unrealistic expectations about future price growth and little understanding of the basic economics of housing markets. Typically, housing prices adjust back to their historic norms, so that if prices rise, relative to historic trends, by an additional $\$ 10$, o0o over one five-year period, those prices should be expected to fall (again, relative to trend) by $\$ 3,200$ over the next five-year period. ${ }^{2}$ Yet during booms, economists Karl Case and Robert Shiller have found, buyers typically expect growth to continue. ${ }^{3}$ Such irrational exuberance was clearly present in Las Vegas in 2006, when home buyers paid more than twice as much as buyers had only six years earlier.

The price booms in Las Vegas and Phoenix are particularly hard to recon- cile with informed housing acquisition. These areas have few limits on new construction, and builders supply new housing for less than $\$ 100$ per square foot. The power of unfettered building has long kept prices low despite decades of enormous growth. But while these markets did not see price growth during the boom of the late 1980 s, buyers in Phoenix and Las Vegas must have assumed that their regions were headed for a permanently higher price plateau. Subsequent events have proven that, to the contrary, unrestricted construction will, in the medium run, keep prices low.

While we do not yet understand the reason for the whirlwind that coursed through the housing markets, we can draw a major policy lesson from the cycle. For decades, the U.S. government has pushed homeownership with policies that subsidize mortgage rates and encourage borrowing. The bust reminds us that housing prices move down as well as up. Promoting homeownership by subsidizing borrowing now seems as likely to create a "default nation" as it does an "ownership nation." Federal policies that encouraged home buyers to leverage themselves to the hilt in order to bet on housing were clearly complicit in the debacle. As the crash has demonstrated, it is time to rethink these policies.

$\mathrm{Th}$ he home mortgage interest deduction, the sacred cow of federal housing guidelines, was not originally meant to serve as a housing policy. It was introduced with the income tax law in 1916, when essentially all interest payments were deductible. Home mortgages were a minor form of borrowing at that time; the deductibility of interest was largely used to make business expenses tax deductible. Although the Tax Reform Act of 1986 eliminated the deductibility of 
non-mortgage interest payments, by then the majority of Americans were homeowners, and the home mortgage interest deduction had become untouchable. Today, the deduction is restricted to mortgages of less than $\$ 1$ million, or to the first $\$ 1$ million of mortgages above that amount, though in 2005, President Bush's tax reform panel unsuccessfully proposed a substantial reduction of that upper limit.

In the wake of the Great Depressionera housing crisis, the federal government pursued a number of interventions to reinvigorate the moribund credit market. The National Housing Act created the Federal Housing Administration (FHA) in 1934; it encouraged home buying by insuring mortgages against default. The FHA has typically charged borrowers a significant "up-front" mortgage insurance charge (equal to 2.25 percent of the mortgage during mid-2010 $)^{4}$ and has financed itself from that fee. ${ }^{5}$ In fact, during the early postwar period, the organization received criticism from the left for being too stingy and refusing insurance to borrowers and neighborhoods that the FHA deemed higher risk. During the same period, the Veterans' Administration (VA) also became a significant insurer of new mortgages at belowmarket rates; recent evidence uncovered by economist Dan Fetter suggests that the va had a significant impact on homeownership. The FHA was relatively inactive during the recent boom, as private insurers offered better terms; in 2009, however, one-third of all new mortgages were FHA-insured.

In 1938, the FHA was joined by the Federal National Mortgage Association (Fannie Mae), which was also intended to encourage bank lending. While the FHA insured mortgages, Fannie Mae actually bought mortgages from banks, freeing capital and allowing banks to make more loans. When Fannie was privatized in the 1960s, the Federal Home Loan Mortgage Corporation (Freddie Mac) was created to generate competition. During the 1970s, Freddie and Fannie moved - with private-sector partners like Salomon Brothers - into the securitization business. They moved from holding mortgages on their own balance sheets to becoming pass-through agencies that bundled and insured mortgages for resale on the secondary market. Fannie Mae and Freddie Mac used a variety of criteria, such as debt-to-income ratios, credit rating, and mortgage size, to determine whether a particular loan conformed to quality standards and could be securitized. Like the FHA, Fannie Mae and Freddie Mac primarily impacted housing markets by allowing better credit terms. A third player, the Government National Mortgage Association (Ginnie Mae), also insures mortgagebacked securities and does so with the full faith and credit of the U.S. government. Ginnie Mae's role is considerably more modest, however, because it insures securities representing mortgages that already have a guarantee from the FHA, VA, or another federal source.

During most of their post-privatization history, these enterprises steadfastly claimed that their profits reflected the benefits that came from the large, liquid market in mortgage-backed securities created by the vast scale of their operations, not implicit government guarantees. Those claims were never terribly plausible, and they certainly are not so today, as the agencies are now kept alive only through tax dollars. Although these entities continue to be subsidized primarily because their failure would further damage the economy, historically, Fannie Mae was justified as a means of solving market imperfections in the secondary mortgage market. Because banks
Housing policy in the wake of the crash 
Edward L.

Glaeser

on the

financial

crisis \&

economic policy have an incentive to keep high-quality mortgages on their books and sell only the worst mortgages on any secondary market, the fact that Fannie Mae and Freddie Mac guaranteed mortgages was supposed to prevent a market breakdown. Today, however, a large market in private mortgage insurance permits securities backed by jumbo mortgages, credit card debt, and commercial credit to trade comfortably in the secondary market without an implicit federal guarantee.

The majority of federal housing policies are either less significant or less problematic. Section 8 housing vouchers provide housing-related aid to poorer Americans, who typically rent. Economists generally accept this intervention as a reasonable form of market-oriented inkind redistribution. The Low-Income Housing Tax Credit subsidizes the production of affordable housing nationwide. The credit, however sensible in places where housing is expensive, such as along America's coasts, is less tenable in the case of construction-crazy Atlanta or depressed Detroit. I am no fan of the tax credit, but I will restrict my discussion to the even bigger interventions the home mortgage interest deduction, the FHA, and the Government-Sponsored Enterprises (GSEs) - that encourage people to buy homes by borrowing cheaply.

In 2009 and 2010, the Federal Reserve bought $\$ 1.25$ trillion worth of mortgagebacked securities, allegedly "to provide support to mortgage and housing markets and to foster improved conditions in financial markets more generally." 6 The vast size of this purchase certainly suggests the large public cost of Fannie Mae and Freddie Mac, but the intervention itself had far more to do with avoiding a financial market meltdown than with supporting housing markets. This essay focuses on the housing policies that helped create the crisis, not on the interventions - like the purchase of mortgage-backed securities - that tried to prevent the Great Recession from turning into a second Great Depression.

$\mathrm{B}$ lic objectives that underlie housing interventions and, in theory, justify the existence of the FHA, Fannie Mae, and Freddie Mac. The first is narrowly related to imperfect information in credit markets. For at least four decades, economists have understood that a "lemons" problem - whereby borrower and lender have asymmetric information - may hamper insurance or lending markets. In principle, the lending market could break down if some borrowers face a higher cost (psychic or otherwise) of default than others and if those borrowers (but not their lenders) know the costs of default. If lenders cannot distinguish between high and low risk and, in turn, charge all borrowers the same rate, then it is possible that high-risk borrowers will be more likely to borrow while lowrisk borrowers may choose to self-finance or, less plausibly, rent. In this scenario, the high-risk borrowers are willing to pay the high interest because they have a greater chance of defaulting, or exercising their option not to repay the loan. If only risky borrowers go to banks, then interest rates will be extremely high, in which case the safe borrowers who will never default may prefer to avoid the market altogether. A vicious circle results in which risky borrowers cause high interest rates, and high interest rates deter safe borrowers. The FHA is tasked with preventing this scenario by creating a more liquid market that does not charge prohibitively high rates.

A similar breakdown can occur in the secondary market for mortgages if mortgage issuers know more about a mort- 
gage's quality than any prospective buyer. The U.S. Securities and Exchange Commission case filed against investment banking and securities firm Goldman Sachs in April 2010 hinges squarely on whether the firm had material private information about mortgage-backed securities that it failed to disclose. More generally, mortgage issuers, like banks, have an incentive to keep the good mortgages on their own balance sheets and sell only the bad mortgages to outside investors. This lemons problem in the secondary market can impede the development of a risk-sharing mortgage market and lead banks to hold housing risk in their own portfolios. If bank defaults carry systemic consequences, either because of federal deposit insurance or because a failure of the banking system threatens the entire economy, then the country has an interest in developing a secondary market to spread mortgage risk more widely. By creating a subsidy so that all mortgages, at least within a given class, are resold, Fannie Mae and Freddie Mac can help that lemons problem disappear.

These asymmetric information problems are real, but are they large enough to justify the vast public subsidies that now exist? Do the public subsidies actually solve the problems? A remarkably large body of information about borrowers and their credit histories is available to banks and could be provided to purchasers of mortgage-backed securities. The fact that many lenders were sloppy in the run-up to the crash and ignored this information does not help the case for public insurance, which only mutes the incentives for due diligence. Moreover, an abundance of lending occurs without the benefit of public insurance. Many mortgages are securitized without the help of Fannie Mae and Freddie Mac. Arguably, the FHA and Fannie Mae made sense during the Great Depression but are less relevant today. It is particularly hard to justify the existence of for-profit entities that deal in mortgages with the aid of an implicit government guarantee.

A second reason for public intervention in the mortgage markets is the desire to encourage Americans, especially veterans, to consume more housing. In 1940, 45 percent of America's housing units lacked complete plumbing facilities, and 20 percent housed more than one person per room. ${ }^{7}$ Nostalgia for prewar housing is misguided: the attractive older homes that remain are the homes that were nice enough to keep around. The typical prewar home was terrible by modern standards.

Prewar America provided at least three defensible reasons for the government to encourage housing consumption. First, tiny homes that lacked plumbing were often unsanitary and helped spread disease. The externalities from contagious illness were a primary motivation for the progressive reformers who focused on improving housing conditions in America's cities. Second, Americans have often been more comfortable with in-kind transfers, like food stamps, then with outright cash grants. It was surely an easier political sell to support better housing than to support higher welfare payments. Even "Mr. Republican," Robert Taft, was an advocate of federal housing assistance. Third, some have argued that better housing implicitly helps children by providing a healthier and safer environment. Recent research on Section 8 housing vouchers has found that voucher recipients move to neighborhoods with less crime and less exposure to environmental irritants that may trigger asthma. ${ }^{8}$

It is hard to justify mortgage-related interventions with this line of reasoning today. Essentially all Americans have ad-
Housing policy in the wake of the crash 
Edward L. Glaeser on the financial crisis \& economic policy equate plumbing, and even the poorest quintile of the population enjoys an average of 855 square feet of living space per capita. Indeed, the average amount of housing space consumed among the poorest fifth of Americans is nearly double the population-wide average in France, Germany, and the United Kingdom. ${ }^{9}$ Americans are now, by either historic or world standards, spectacularly well housed.

The third standard justification for mortgage-related interventions is that they encourage homeownership and its (alleged) attendant social benefits. Certainly, homeowners are more likely to vote, go to church, garden, know the name of their U.S. representatives, and say that they "work to solve local problems." 10 Economists have struggled to identify whether these effects represent a causal effect of homeownership, whereby owning a house creates better citizens, or whether the reverse is true: people who are inclined to good citizenship are more likely to become homeowners.

One approach to this problem has been to look at people over time, tracking whether their citizenship-related activities change with homeownership status. Using data on homeownership and civic involvement in Germany, economist Denise DiPasquale and I have found that a change indeed occurs when people become homeowners, but the effect is much smaller than that estimated by comparing homeowners and renters. ${ }^{11}$ We have also attempted other - perhaps less convincing - means of estimating the causal link between ownership and citizenship. For example, we find that much of the impact of homeownership appears to come simply from length of time lived in the community. When people stay in one place, they develop ties and work more for communal aims.
The case for homeownership is also supported by the view that it leads to asset accumulation. Certainly, homes are the primary asset for many Americans, and rising home values have made many people wealthier. Various political leaders, including former President George W. Bush, have thought that America would be better off if more people had more capital and as a result have promoted homeownership as a means of achieving an "ownership society."

Economist David Albouy has provided a more original argument for the home mortgage interest deduction. Income taxes influence many personal decisions, such as how many hours to work or how much money to save; economists typically consider these artificial influences, called distortions, to be unfortunate. ${ }^{12}$ Income taxes also distort decisions about where to live by disproportionately taxing people who live in highly productive, high-wage areas like Boston and New York. Albouy argues that the home mortgage interest deduction makes up for some of this distortion by providing greater benefits for people living in high-cost areas, which tend to offer higher wages. ${ }^{13}$

T he real benefits of federal housing policy must be stacked against the costs. Perhaps the most obvious disadvantage of the home mortgage interest deduction is its highly regressive character. Economists James Poterba and Todd Sinai have estimated that the average homeowning household earning between $\$ 40,000$ and $\$ 75$, 000 per year receives an annual tax benefit of $\$ 523$ from the deduction. An average homeowning household that earns more than $\$ 250$, ooo per year receives a benefit of $\$ 5,459 .{ }^{14}$ These estimates assume - no doubt incorrectly - that behaviors would not change if the de- 
duction were eliminated. However, we have no good way of estimating how many people would pay off their mortgages were the deduction eliminated.

Less attention has been paid to the progressivity of subsidies implicit in the FHA, Fannie Mae, and Freddie Mac. The FHA provides insurance only for less expensive homes and moderateincome individuals, though in the past, it has been accused of bias against minorities and poorer neighborhoods. Likewise, Fannie Mae's and Freddie Mac's benefits typically go to a middle section of the U.S. income distribution. These programs certainly are not strongly progressive - the very poor are less likely to be homeowners - but they are also far less regressive than the home mortgage interest deduction.

The regressive nature of the deduction should be part of any public discussion about reform. To an economist, however, regressivity is not intrinsically damning. After all, the income tax as a whole is highly progressive, and the regressivity of a particular deduction must be considered within that larger context. Even more important, the tools of economics do not naturally allow us to consider the virtues of taking from one group of citizens and giving to another. That discussion is the province of philosophers and politicians.

More aptly, the tools of economics are designed to judge the impact of these mortgage subsidies on potential homeowners' behavior. The subsidies do more than just encourage homeownership; they have significant, usually negative, side effects - at least from the perspective of mainstream economics, which generally views unjustified distortions of behavior as negative.

Perhaps the most obvious distortion is that the subsidies encourage people to invest excessively in housing relative to other forms of capital. Indeed, providing Housing incentives for people to buy bigger homes may not make much sense in a country where homes are already extremely large. policy in the wake of the Larger homes typically use more energy, ${ }^{15}$ and if carbon emissions damage the environment, then pushing people to buy large, energy-intensive dwellings has costs.

By pushing homeownership as a source of asset accumulation, the government ensures that individual portfolios will be highly skewed toward housing wealth. As we have just seen, housing wealth is hardly risk-free. Moreover, individual wealth levels are often enormously sensitive to changes in the housing market. Private buyers and lenders ultimately bear primary responsibility for the defaults and bankruptcies that have followed the housing collapse, but by encouraging individuals to borrow to bet on housing, the government bears some auxiliary responsibility.

Any housing subsidy would encourage individuals to invest too heavily in housing - relative to uninfluenced decision-making - but mortgage subsidies in particular encourage people to leverage themselves to the hilt. Even before the recent boom, in 1998, 3.9 percent of new mortgages had loan-tovalue ratios above 95 percent. Enabled by subsidized mortgage interest, individuals typically refinance their homes to get cash out. In turn, home buyers have debt-financed portfolios, the value of which fluctuates wildly with the state of the housing market.

As Todd Sinai and Nick Souleles ${ }^{16}$ have argued, owning a home is itself something of a hedge. People are born into the world short of housing. Renters bear housing-price risk associated with changes in rental costs. At its best, homeownership provides protection against these fluctuations in rental costs, 
Edward L. Glaeser on the financial crisis \& economic policy but for people who anticipate moving or trading down, homeownership also creates portfolio risk. Policy that encourages people to borrow as much as possible to invest in just one asset class is of dubious value.

Subsidizing homeownership and housing consumption also impacts urban form. There is a tight connection between structure type and ownership type. More than 85 percent of people who live in single-family detached homes own their residences. More than 85 percent of people who live in structures with five or more units rent. This pattern provides good incentives for maintaining single-family homes and avoiding inter-owner conflict in multifamily dwelling. Single-family detached houses depreciate by an additional 1 percent per year when they are occupied by renters who fail to provide the sweat equity needed for maintenance. As those familiar with co-op boards can attest, the costs of spreading ownership of one large structure across a large number of owners underscore the benefits of having one owner for each roof.

But single-family detached houses are typically in suburbs while apartments are typically in cities. High land values in the urban core push structures upward. Seventy-six percent of Manhattan residents rent; 64 percent of residents in nearby Westchester County own. ${ }^{17}$ By subsidizing homeownership, the government implicitly encourages people to leave cities and move into single-family detached houses elsewhere.

There are good reasons to question the many government policies, including subsidies to agriculture and highway construction, which tilt against urban areas. In many cases, suburbs are far more homogeneous than cities, and encouraging suburbanization pushes people to live in segregated polities.
Suburban living normally entails more energy use because of larger homes and longer commutes. ${ }^{18}$ Much of the world's economic and cultural innovations occur in cities, and if such urban-centered activity generates wider social benefits, then discouraging city living carries further social costs.

Finally, homeowners are less mobile and less able to respond to economic shocks. Economist Andrew Oswald has found that, across European regions, unemployment is highest where homeownership is highest. This fact does not hold in the United States, but his argument has merit, especially in declining regions. Should public policy really be encouraging poorer Americans to buy property, tying them to cities that seem locked in long-run decline?

A housing market crash creates two
opposite pressures on government pol-
icy. On one side, it exposes the folly of
government policies that push people to
bet on housing markets. On the other, it
produces a dangerous climate in which
to attempt new policies that could de-
press the housing markets even more.
One force pushes toward reform, the
other toward the status quo.

As of May 2010, the housing market seemed somewhat less poised on the brink of further disaster. Between May 2009 and January 2010, housing prices remained relatively steady in much of the country. In Las Vegas and Phoenix, prices had returned to their historic norms, which are closely related to construction costs. If recent trends provide any guide, the housing market can be quite stable for many years after prices level off. For example, between March 1991 and May 1997, the Case/Shiller tencity index neither rose nor fell more than 2.5 percent in nominal terms relative to its March 1991 level. It is therefore rea- 
sonable to contemplate appropriate housing reforms as long as those reforms are implemented gradually and with care.

The most promising target is the home mortgage interest deduction. Even if the goal of homeownership is considered sacrosanct, there are far better ways to promote it. The deduction not only has a number of harmful side effects, like encouraging borrowing and extra housing consumption, but it is also poorly targeted. The biggest benefits of the deduction accrue to the wealthy, who are likely to be homeowners regardless of tax policy. Less prosperous Americans, who are as equally likely to own a home as they are to rent, often fail to itemize the deduction even if they are homeowners. In fact, more than three-quarters of homeowners do not itemize; the poorest four-tenths of Americans take the standard deduction. ${ }^{19}$

For this group, the mortgage interest deduction does little, if anything. Over time, the deduction greatly increases in value during expected periods of high inflation because nominal interest can be deducted, yet there is hardly an observable increase in homeownership during periods when the deduction becomes more valuable. Across states, the size of the benefit (or changes in the size of the benefit) has no apparent effect on homeownership.

To increase homeownership without encouraging excessive borrowing or bigger homes, the natural tool would be a flat homeowner's tax credit. This tax credit could be independent of the size of the house or mortgage, would reduce tax payments for every American who owns his or her own home, and could be included on top of the standard deduction. This clear, tangible tax benefit would accrue to the owner regardless of the size or value of the home, and would thus be far less tilted toward the rich. Inevitably, homeowners will tend to be wealthier, and a tax credit likely will not benefit people who do not pay taxes. Nevertheless, even though a flat homeowner's tax credit would still encourage migration from cities and would still give more benefits to the rich, it would be far less regressive and distortionary than the current policy.

As a somewhat more politically feasible policy approach, the cap on the home mortgage interest deduction might be lowered from $\$ 1$ million to, say, $\$ 300,000$, as suggested by the 2005 Tax Reform Panel. A simple, gradual method of implementing this change would be to reduce the deduction cap by $\$ 100,000$ per year for the next seven years. To a small degree, the cap would limit the incentive to invest in larger homes or borrow extreme amounts, but this approach would be decidedly second-best relative to the straight tax credit; for most Americans, it would preserve strong incentives to borrow and buy large homes.

The FHA, Fannie Mae, and Freddie Mac present a thornier problem. It is reasonable to argue that the FHA does solve a genuine market failure. Moreover, it provides for lower income Americans and is thus the least attractive candidate for major reform. The FHA has taken on a great deal of risk, but by slightly raising fees, it can easily accumulate enough capital to continue to cover its costs.

The case for a major overhaul of Freddie and Fannie is considerably stronger. At the time of this writing, many estimates for the taxpayer losses paid by Fannie and Freddie were upwards of $\$ 300$ billion. ${ }^{20}$ Any subsidy to homeownership can be created directly through the tax system; there is little apparent need for a second,
Housing policy in the wake of the crash 
Edward L. less visible subsidy operating through Glaeser on the financial crisis \& economic policy

government-sponsored enterprises.

These public agencies may not need to exist at all, but if they do, they will probably function best as slow-moving, highly regulated public utilities, with a mandate limited to insuring, bundling, and selling mortgage-backed securities. One model suggests reinstating them as a strong, independent public entity, with a governance structure vaguely resembling that of the Federal Reserve Board. The GSEs have often been thought to wield much weight on Capitol Hill, and lawmakers have often supported an expansion of their activities, as long as this expansion was joined with other activities that lawmakers found desirable. A better model would establish a national mortgage insurer with a greater degree of separation from politics and the profit motive.

National mortgage insurers should be required to refrain from all activities other than the insuring, bundling, and selling of mortgages. There is no reason for these entities to hold hundreds of billions of dollars of mortgage-backed securities in their own portfolios, as they did before the crash. If the agency is meant to solve market failures that challenge a purely private secondary mortgage market, then it should stick to that function.

A revamped public mortgage insurer would continue to charge a guarantee fee based on borrowers' loan-to-value and credit score. However, fees can be conservatively high. Moreover, the national mortgage insurer, like the Federal Reserve Board, should recognize that housing prices are not like stocks. They do not typically follow a random walk but, rather, show considerable mean reversion over five-year horizons. To correct this phenomenon, guarantee fees should be based not only on the ratio of loan-to-purchase price, but also on the ratio of loan-to-expected resale value, which may be considerably lower.

For example, in markets that have risen considerably, expected resale value will be lower than current prices because prices tend to revert to historic norms. In markets where there is little restraint on building and land is abundant (which is the case in much of America), expected resale value should be tied to construction costs - despite the vicissitudes of current prices - with the expectation that prices will eventually return to the costs of delivering housing. While it is a mistake to put too much faith in any forecasting model, the evidence for mean reversion is sufficiently strong that requiring higher guarantee fees in places that have experienced significant recent price increases is a solid policy approach. If this policy had been followed during the boom, then guarantee fees would have become much higher during the booms of Phoenix and Las Vegas. The higher fees would have both protected the GSEs against risk and perhaps also helped check the wild swings in prices.

It is, of course, quite possible that an excessively conservative national mortgage insurer will charge too much, but that is a fairly minor problem as long as there are no barriers to free entry in the market for mortgage insurance. If private insurers offer better and cheaper products, then the public entity will not have much business, which is perfectly acceptable, at least as long as the private insurers cannot offer an implicit government guarantee of their own. The national mortgage insurer should guarantee that the secondary mortgage market does not disappear; that is its primary function.

The great national housing convulsion
bears two major lessons: housing mat- 
ters and prices fall as well as rise. Ordinary home buyers and the global financial system can suffer enormously when housing markets crash. It is neither possible nor desirable to legislate housing bubbles out of existence; the human capacity for over-optimism is just too strong. But it is both possible and desirable to limit the public role in encouraging those bubbles and to reduce the suffering they cause. We can reduce the public subsidies that encourage people to borrow as much as possible to make risky investments in housing.

The tax code is currently geared to induce mortgage debt. Every buyer who bought during the boom had the blessing of a government that encouraged homebuying through rhetoric and the tax code. Additional subsidies were provided by the governmentsponsored enterprises, which insured mortgages at a cost that now seems too low. These policies artificially encouraged borrowing.

Even if America wants to encourage homeownership, it does not need to encourage borrowing or buying big homes. A simple, moderate homeowner's tax credit would encourage homeownership more fairly and with fewer distortions. A plodding, conservative public mortgage insurer that charges relatively high fees can ensure the existence of a secondary mortgage market with less risk to taxpayers and less excessive borrowing. The housing crash exposed the folly of subsidizing leveraged bets on housing. It would be a shame if we ignore that lesson.

\section{ENDNOTES}

${ }^{1}$ Edward L. Glaeser, Joshua D. Gottlieb, and Joseph Gyourko, “Can Cheap Credit Explain the Housing Boom?” NBER working paper 16230 (National Bureau of Economic Research, 2010).

2 Edward L. Glaeser and Joseph Gyourko, “Housing Dynamics,” NBER working paper 12787 (National Bureau of Economic Research, 2006).

3 Karl E. Case and Robert J. Shiller, "The Behavior of Home Buyers in Boom and PostBoom Markets," in Stock Market Crashes and Speculative Manias, ed. Eugene N. White, Elgar Reference Collection, International Library of Macroeconomic and Financial History, no. 13 (Cheltenham, U.K. ; Brookfield, Vt. : Elgar, 1996), 314-330 (distributed by Ashgate).

4 http://www.hud.gov/offices/adm/hudclips/letters/mortgagee/files/10-o2ml.pdf.

5 This fee, called the "up-front" fee, is paid at closing, but lenders often roll the fee into the loan, so that the "up-front" fee is paid off over many years. The FHA also charges an annual mortgage insurance fee.

6 http://www.newyorkfed.org/markets/mbs_faq.html.

7 Edward L. Glaeser and Joseph Gyourko, "Rethinking Federal Housing Policy” (Washington, D.C. : AEI Press, 2009).

8 Lawrence F. Katz, Jeffrey R. Kling, and Jeffrey B. Liebman. "Moving to Opportunity in Boston: Early Results of a Randomized Mobility Experiment," Quarterly Journal of Economics 116 (2) (May 2001): 607 - 654.

9 Glaeser and Gyourko, "Rethinking Federal Housing Policy."

10 Denise DiPasquale and Edward L. Glaeser, "Incentives and Social Capital: Are Homeowners Better Citizens?” Journal of Urban Economics 45 (2) (March 1999): 354-384.

Housing policy in the wake of the crash 
Edward L. $\quad{ }^{11}$ Ibid.

Glaeser

on the

financial

crisis \&

economic policy
12 David Albouy, “The Unequal Geographic Burden of Federal Taxation,” Journal of Political Economy 117 (4) (August 2009): 635-667.

13 The correlation across metropolitan areas between median incomes and median property values in the 2000 U.S. Census was 67 percent. Joseph Gyourko and Todd Sinai provide a summary of the geography of the home mortgage interest deduction, demonstrating that the benefits accrue primarily to richer areas ; Joseph Gyourko and Todd Sinai, "The Spatial Distribution of Housing-Related Ordinary Income Tax Benefits," Real Estate Economics 31 (4) (Winter 2003): 527-575.

14 James Poterba and Todd Sinai, “Tax Expenditures for Owner-Occupied Housing: Deductions for Property Taxes and Mortgage Interest and the Exclusion of Imputed Rental Income," American Economic Review 98 (2) (May 2008): 84-89.

15 Edward L. Glaeser and Matthew E. Kahn, “The Greenness of Cities: Carbon Dioxide Emissions and Urban Development," Journal of Urban Economics 67 (3) (May 2010): 404-418.

16 Todd Sinai and Nick S. Souleles, “Owner-Occupied Housing as a Hedge Against Rent Risk," Quarterly Journal of Economics 120 (2) (May 2005): 763-789.

17 The U.S. Census, American Factfinder, is the source of both figures, which refer to the $2006-2008$ period.

18 Glaeser and Kahn, "The Greenness of Cities."

19 Edward L. Glaeser and Jesse M. Shapiro, "The Benefits of the Home Mortgage Interest Deduction,” Tax Policy and the Economy 17 (2003): 37 - 82.

20 http ://www.bloomberg.com/apps/news ?pid=email_en\&sid=a2Z5GnTAPcuo. 